\title{
PEMILIHAN DAN PEMBENTUKAN PORTOFOLIO SAHAM LQ45 YANG OPTIMAL \\ (STUDI KASUS DI BURSA EFEK INDONESIA (BEI))
}

\author{
Desy Wahyuningrum \\ Fakultas Ekonomi Universitas Brawijaya
}

\begin{abstract}
This article aims to identify how investor choose and decide an optimal portfolio of stock, using Markowitz and Single Index Model. The analysis on 45 Shares in the group of LQ45 in Indonesia Stock Exchange (IDX), found that the optimal portfolio would be composed of 11 share: TRUB (Truba Alam Manunggal Engineering Tbk), BUMI (Bumi Resources Tbk), TINS (Timah Tbk), BNBR (Bakrie \& Brothers Tbk), BBNI (Bank Negara Indonesia Tbk), and ELTY (Bakrieland Development Tbk). As a comparison of risk and return of optimal and non-optimal portfolio, the optimal portfolio had $14.6 \%$ return and $1.6 \%$ risk, while the non-optimal had only $7.8 \%$ return and $0.13 \%$ risk.
\end{abstract}

Keywords: Markowitz Model, Single Index Model, LQ45, Indonesia Stock Exchange, optimal portfolio, risk, return

\section{A. LATAR BELAKANG}

Salah satu bidang investasi yang cukup menarik adalah saham. Mirip dengan pedagang, motivasi seorang investor untuk melakukan investasi pada saham tak lain adalah untuk mendapatkan keuntungan. Investor mengharapkan pembagian dividen (dividend income) dan keuntungan dari kenaikan harga saham (capital gain), karena saham bisa dijual dengan harga yang lebih tinggi. Tetapi dunia investasi saham juga penuh dengan ketidakpastian atau risiko (Fardiansyah, 2002).

Keputusan pilihan investasi lebih banyak pada pertimbangan aspek fundamental perusahaan berupa emiten yang berkinerja baik, atau yang dapat memberikan dividen menarik. Karena itulah, pilihan investasi jatuh pada saham yang tergolong pada kelompok LQ 45.

Sebuah pepatah sering mendasari kegiatan investasi di pasar modal guna menghindari besarnya risiko investasi yang mungkin ditanggung yaitu, "Don't put all your eggs in one basket" (jangan letakkan semua telur anda dalam satu keranjang). Jika kita menanamkan dana yang kita miliki hanya pada satu saham, ada kemungkinan kita akan menderita kerugian yang besar jika kondisi buruk menimpa perusahaan yang menerbitkan saham tersebut. Oleh karena itu investor dapat melakukan diversifikasi dengan mengalokasikan dana pada beberapa saham dari perusahaan yang berbeda. Kombinasi saham ini disebut dengan portofolio saham.

Menurut Fabozzi (1999:61) teori portofolio berhubungan dengan pemilihan portofolio yang dapat memaksimalkan pengembalian yang diharapkan sesuai dengan tingkat risiko yang dapat diterima. Dengan menggunakan model kuantitatif dan data historis, teori portofolio mendefinisikan "pengembalian portofolio yang diharapkan" dan "tingkat risiko portofolio yang dapat diterima" serta menunjukkan cara pembentukan portofolio yang optimal.

Masalah yang akan diteliti dapat dirumuskan dalam bentuk pertanyaan sebagai berikut (1). Bagaimana pemilihan portofolio saham yang optimal pada perusahaan yang tercatat dalam LQ 45 di Bursa Efek Indonesia (BEI) dan (2). Saham mana saja yang masuk dalam portofolio optimal dan berapa besar proporsi dana yang sebaiknya diinvestasikan pada masing-masing saham. 


\section{Pemilihan dan Pembentukan Portofolio \\ Wahyuningrum}

\section{B. KAJIAN TEORITIS}

Pergerakan harga saham ditentukan oleh demand dan supply dari saham tersebut. Jika demand meningkat, maka harga saham akan naik. Sebaliknya, harga saham akan turun jika demand menurun. Ada beberapa faktor yang mempengaruhi pergerakan harga saham akibat perubahan demand dan supply, yakni pergerakan suku bunga bank, tingkat inflasi, nilai tukar rupiah, kinerja perusahaan (yang dilihat dari laba dan deviden), serta faktor sosial dan politik.

Terdapat banyak metode yang dapat digunakan untuk mengetahui hubungan variabel makro ekonomi terhadap pasar modal suatu negara. Salah satu teori yang sering digunakan adalah Arbitrage Pricing Theory (APT) yang dikembangkan oleh Chen (1986). Konsep ini merupakan model keseimbangan yang menggunakan hukum satu harga (the law of one price), dimana dua kesempatan investasi yang identik sama tidak bisa dijual dengan harga yang berbeda. Dengan menggunakan APT, Chen (1966) membuktikan bahwa variabel makro ekonomi memiliki pengaruh yang sistematik terhadap return pasar saham. Kekuatan perekonomian mempengaruhi tingkat diskonto kemampuan perusahaan untuk menggerakkan aliran kas dan pembayaran deviden di masa yang akan datang.

Variabel-variabel fundamental ekonomi makro dalam mempengaruhi fluktuasi kurs dapat dikaji dengan beberapa model kurs valas dengan pendekatan moneter dengan menggunakan dasar teori paritas daya beli (purchasing power parity) dan paritas suku bunga (interest rate parity). Salah satu teori yang digunakan untuk menjelaskan kurs mata uang adalah teori Paritas Daya Beli (purchasing power parity). Teori paritas daya beli ini menyatakan bahwa kurs mata uang antar negara harus mencerminkan nilai perbandingan nilai mata uang satu negara terhadap negara lainnya yang ditentukan oleh daya beli masing-masing negara. Hubungan antara kurs dan harga komoditas dalam teori paritas daya beli yaitu kurs akan cenderung menurun dengan proporsi yang sama dengan kenaikan harga.

Teori paritas daya beli terdiri dari dua macam yaitu: paritas daya beli absolut dan paritas daya beli relatif. Paritas daya beli absolut menjelaskan bahwa keseimbangan nilai mata uang dalam negeri terhadap nilai mata uang luar negeri adalah perbandingan harga absolut dalam dan luar negeri. Paritas daya beli absolut ini selanjutnya menghasilkan hukum satu harga (law of one price) yang menjelaskan bahwa untuk satu jenis barang yang sama, maka harga di tempat lain juga harus sama. Paritas daya beli relatif menjelaskan bahwa kurs merupakan persentase perbandingan perubahan harga absolut dalam negeri terhadap luar negeri.

Asumsi utama yang mendasari teori paritas daya beli adalah bahwa pasar komoditi merupakan pasar yang efisien baik dari segi alokasi, operasional, penentuan harga, dan informasi. Asumsi ini selanjutnya menyatakan bahwa (Kuncoro, 1993): (1) Semua barang merupakan barang yang diperdagangkan di pasar internasional (tradable goods) dan tidak ada biaya transportasi; (2) Tidak ada restriksi-restriksi dalam perdagangan internasional; (3) Barang dalam negeri dan luar negeri bersifat homogen sempurna untuk masing-masing barang; (4) Terdapat kesamaan indeks harga yang digunakan untuk memperhitungkan daya beli mata uang asing dan domestik, terutama untuk indeks harga dan elemen indeks harga.

Paritas suku bunga (interest rate parity) merupakan teori yang paling dikenal dalam keuangan internasional. Teori paritas suku bunga ini mengasumsikan nilai kurs berdasarkan tingkat bunga antar negara yang bersangkutan. Dalam negara dengan sistem kurs bebas, tingkat bunga domestik (i) cenderung disamakan dengan tingkat bunga luar negeri ( $\left.i^{*}\right)$ dengan memperhitungkan perkiraan laju depresiasi mata uang negara yang bersangkutan terhadap negara lain (Baillie dan McMohan, 1990). Teori paritas suku bunga terdiri dari dua macam yaitu: paritas suku bunga tertutup (covered interest rate parity) dan paritas suku bunga tidak tertutup (uncovered interest rate parity).

Paritas Suku Bunga Tertutup (Covered Interest Rate Parity) menjelaskan bahwa terdapat hubungan antara kurs spot, kurs forward, dan variabel suku bunga. Paritas suku bunga tertutup ini menjelaskan hubungan yang erat antara suku bunga dengan pergerakan kurs spot dan kurs forward mata uang tertentu khususnya mata uang keras (hard currency) seperti dolar Amerika dan Yen Jepang. Paritas suku bunga tertutup dipandang sebagai dasar yang lebih relevan untuk menjelaskan 
kurs valas. Penjelasan tentang bekerjanya mekanisme paritas suku bunga tertutup, yaitu dengan menggunakan hubungan dua negara dengan nilai mata uang dan suku bunga masing-masing negara, dengan asumsi terdapat keterbukaan antar negara.

Paritas Suku Bunga Tidak Tertutup (Uncovered Interest Rate Parity) juga digunakan untuk menganalisis model kurs valas. Dalam teori paritas suku bunga tidak tertutup, diasumsikan pasar yang efisien terjadi bila kurs forward merupakan peramal yang tidak bisa untuk nilai kurs spot pada masa yang akan datang. Hubungan tingkat bunga dengan nilai tukar mata uang didasarkan pada ini yaitu suatu kondisi dimana expected return dari deposito atau tabungan dari 2 mata uang adalah sama (kondisi equilibrium). Pendekatan ini menggunakan asumsi adanya perfect capital mobility dan instrumen keuangan di kedua negara bersifat perfectly substitutable. Dengan demikian, jika tingkat bunga luar negeri lebih besar dibandingkan tingkat bunga dalam negeri, maka nilai tukar domestik akan terapresiasi sebesar perbedaan tingkat bunga tersebut, begitu pula sebaliknya.

\section{METODE DAN ANALISIS DATA}

Penelitian ini merupakan penelitian kuantitatif dengan ruang lingkup saham LQ 45 periode Februari 2008 s/d Juli 2008. Adapun obyek analisis dari penelitian ini adalah 1) harga saham dan dividen bulanan pada masing-masing saham perusahaan yang tercatat dalam LQ 45 diatas, 2) IHSG bulanan dan 3) Suku bunga SBI sebagai return bebas risiko. Periode yang digunakan dalam penelitian adalah selama 60 bulan, yang dimulai dari tahun 2003:2 s.d 2008:1. Jenis data yang digunakan dalam penelitian ini adalah data sekunder yang diperoleh dari internet dan Pojok BEJ Fakultas Ekonomi Universitas Brawijaya.

Untuk memperoleh tujuan dari penelitian ini, maka tahap-tahap analisis yang dilakukan adalah sebagai berikut :

1. Menghitung hasil (return) saham tiap bulan.

$$
R_{i t}=\frac{P_{i t}-P_{i t-1}+D_{i t}}{P_{i t-1}}
$$

Dimana : $\mathrm{R}_{\mathrm{it}} \quad=$ Hasil (return) saham $\mathrm{i}$ pada periode $\mathrm{t}$

$\mathrm{P}_{\mathrm{t}} \quad=$ Harga saham i pada periode $\mathrm{t}$

$\mathrm{P}_{\mathrm{t}-1} \quad=$ Harga saham i pada periode $\mathrm{t}-1$

$\mathrm{D}_{\mathrm{t}} \quad=$ Dividen per bulan

2. Menghitung tingkat pengembalian (return) yang diharapkan atas saham.

$$
E\left(R_{i}\right)=\frac{\sum R_{i t}}{N}
$$

Dimana: $\mathrm{N}=$ Jumlah periode pengamatan

3. Menghitung tingkat pengembalian (return) pasar.

$$
R_{M . t}=\frac{I H S G_{t}-I H S G_{t-1}}{I H S G_{t-1}}
$$

Dimana : $\mathrm{R}_{\mathrm{M} . \mathrm{t}} \quad=$ Tingkat pengembalian (return) pasar,

$\mathrm{IHSG}_{\mathrm{t}}=$ Indeks Harga Saham Gabungan untuk periode $\mathrm{t}$,

$\mathrm{IHSG}_{\mathrm{t}-1}=$ Indeks Harga Saham Gabungan untuk periode $\mathrm{t}-1$.

4. $\quad$ Menentukan beta saham dengan menggunakan time series regresion.

$$
R_{i}=\alpha_{i}+\beta_{i} R_{M}+e_{i}
$$

Dimana : $\alpha_{i} \quad=$ Nilai ekspektasi dari return saham yang independen terhadap return 
pasar,

$\beta_{i}=$ Beta yang merupakan koefisien yang mengukur perubahan $R_{i}$ akibat dari perubahan

$R_{M}$,

$e_{i} \quad=$ Kesalahan residu yang merupakan variabel acak dengan nilai ekspektasinya sama dengan nol atau $E\left(e_{i}\right)=0$

Hasil perhitungan regresi ini dengan menggunakan SPSS 12. Return pasar sebagai variabel bebas dan return saham i sebagai variabel terikat.

5. Menghitung varian dari kesalahan residu yang menunjukkan besarnya risiko tidak sistematik yang unik terjadi di dalam perusahaan i.

$$
\begin{aligned}
& \begin{array}{c}
\sigma_{e i}{ }^{2}=\frac{\sum_{i=1}^{n}\left[e_{i}-E\left(e_{i}\right)\right]^{2}}{n-1} \ldots \ldots \ldots \ldots \ldots \ldots \ldots \ldots \ldots \ldots \ldots \ldots \ldots \ldots \ldots \ldots \ldots \ldots \ldots \ldots \ldots \ldots \\
\text { Dimana }:{\sigma_{e i}}^{2} \quad=\text { Varian dari kesalahan residu }
\end{array} \\
& e_{i} \quad=\text { Kesalahan residu, dengan nilai ekspektasinya sama dengan nol atau } E\left(e_{i}\right)=0 \text {. } \\
& \mathrm{n} \quad=\text { Jumlah periode pengamatan }
\end{aligned}
$$

6. Menentukan rasio antara ekses return dengan beta (excess return to beta ratio / ERB).

Excess return didefinisikan sebagai selisih return ekspektasi dengan return aktiva bebas risiko. Excess return to beta berarti mengukur kelebihan return relatip terhadap satu unit risiko yang tidak dapat didiversifikasikan yang diukur dengan Beta.

$$
E R B_{i}=\frac{E\left(R_{i}\right)-R_{B R}}{\beta_{i}}
$$

Dimana : $E R B_{i}=$ Excess Return to Beta sekuritas ke-i

$$
\begin{aligned}
& E\left(R_{i}\right)=\text { Return ekspektasi untuk sekuritas ke-i } \\
& R_{B R} \quad=\text { Return aktiva bebas risiko } \\
& \beta_{i} \quad=\text { Beta sekuritas ke-i }
\end{aligned}
$$

7. Menentukan saham-saham yang termasuk portofolio optimal, ditentukan dengan langkah sebagai berikut :

1. Urutkan saham-saham berdasarkan nilai ERB terbesar ke nilai ERB terkecil. Saham-saham dengan nilai ERB terbesar merupakan kandidat untuk dimasukkan ke portofolio optimal.

2. Hitung nilai $A_{i}$ dan $B_{i}$ untuk masing-masing saham ke-i sebagai berikut :

$$
\begin{aligned}
& A_{i}=\frac{\left[E\left(R_{i}\right)-R_{B R}\right] \beta_{i}}{\sigma_{e i}^{2}} . \\
& B_{i}=\frac{\beta_{i}^{2}}{\sigma_{e i}^{2}}
\end{aligned}
$$$$
\text { dan }
$$ 
Dimana : $\sigma_{e i}{ }^{2}=$ Varian dari kesalahan residu saham ke-i yang juga merupakan risiko unik atau risiko tidak sistematik.

3. Hitung nilai $C_{i}$ dengan rumus :

$$
C_{i}=\frac{\sigma_{M}{ }^{2} \sum_{j=1}^{i} A_{j}}{1+\sigma_{M}{ }^{2} \sum_{j=1}^{i} \beta_{j}}
$$

4. Besarnya cut-off point $\left(C^{*}\right)$ adalah nilai dimana nilai ERB terakhir kali masih lebih besar dari nilai

5. Saham-saham yang membentuk portofolio optimal adalah saham-saham yang mempunyai nilai ERB lebih besar atau sama dengan nilai ERB di titik. Saham-saham yang mempunyai ERB lebih kecil dengan ERB titik tidak diikutsertakan dalam pembentukan portofolio optimal.

8. Menentukan besarnya proporsi investasi.

Deng

$$
Z_{i}=\frac{\beta_{i}}{\sigma_{e i}{ }^{2}}\left(E R B_{i}-C^{*}\right)
$$

Dimana : $w_{i}=$ Proporsi saham ke-i,

$\mathrm{k}=$ Jumlah saham di portofolio optimal,

$\beta_{i} \quad=$ Beta saham ke-i,

$\sigma_{e i}^{2} \quad=$ Varian dari kesalahan residu saham ke-i,

$E R B_{i} \quad=$ Excess Return to Beta saham ke-i,

$C^{*} \quad=$ Nilai cut-off point yang merupakan nilai $C_{i}$ terbesar.

\section{HASIL DAN PEMBAHASAN}

Dari hasil perhitungan return dan ekspekted return dengan rumus (1) dan (2) diperoleh hasil bahwa tingkat pengembalian/E(Ri) tertinggi ditawarkan oleh saham perusahaan BBNI (Bank Negara Indonesia Tbk), yaitu sebesar 21.5\%. Sedangkan E(Ri) terendah ditawarkan oleh UNVR (Unilever Indonesia Tbk) yaitu sebesar $0,9 \%$. Tingkat pengembalian pasar $\mathrm{E}(\mathrm{Rm})$ dapat dihitung dengan rumus (3) yaitu sebesar 0.034 atau $3.4 \%$. Tingkat return bebas risiko $\left(\mathrm{R}_{\mathrm{BR}}\right)$ diperlukan sebagai ukuran tingkat pengembalian minimum pada saat risiko bernilai 0 . Tingkat return bebas risiko biasanya diukur dengan tingkat suku bunga SBI yang ditetapkan BI. Menurut BI (www.bi.go.id), sejak penerapan ITF pada Juli 2005, arah kebijakan BI ditetapkan melalui besarnya BI rate yang saat ini besarnya $8 \%$.

Saham-saham yang diolah selanjutnya adalah saham-saham yang memenuhi syarat $\mathrm{E}(\mathrm{Ri})>$ 
$R_{B R}$, karena saham-saham yang memiliki $\mathrm{E}(\mathrm{Ri})>R_{B R}$ memiliki tingkat pengembalian minimum yang bebas risiko. Dari 45 saham diperoleh 11 saham yang memiliki syarat $\mathrm{E}(\mathrm{Ri})>$ yaitu sebagai berikut:

Tabel 1. Saham Saham dengan Return di atas Return bebas resiko

\begin{tabular}{cllll}
\hline No & Nama Perusahan & E (Ri) & $R_{B R}$ & $E(R i)-R_{B R}$ \\
1 & B BNI & 0.215 & 0.08 & 0.135 \\
2 & B NB R & 0.115 & 0.08 & 0.035 \\
3 & B NG A & 0.151 & 0.08 & 0.071 \\
4 & BRP T & 0.093 & 0.08 & 0.013 \\
5 & B UM I & 0.128 & 0.08 & 0.048 \\
6 & CPRO & 0.096 & 0.08 & 0.016 \\
7 & ELTY & 0.115 & 0.08 & 0.035 \\
8 & SUL I & 0.083 & 0.08 & 0.003 \\
9 & TINS & 0.098 & 0.08 & 0.018 \\
10 & TRUB & 0.160 & 0.08 & 0.080 \\
11 & UNTR & 0.081 & 0.08 & 0.001 \\
\hline
\end{tabular}

Perhitungan selanjutnya adalah menghitung besar alpha dan beta dengan menggunakan regresi sederhana sesuai dengan persamaan (4) pada program SPSS. Beta menggambarkan sensitivitas perubahan kinerja portofolio dibandingkan dengan kinerja pasar atau merupakan ukuran volatilitas return suatu sekuritas atau return portofolio terhadap return pasar sedangkan komponen return

yang unik diwakili oleh $\alpha_{i}$ (alpha) yang independen terhadap return pasar. BBNI mempunyai nilai beta yang tinggi yaitu 7.003 , hal ini berarti saham tersebut sangat fluktuatif, saham tersebut akan naik dan turun (bergejolak) lebih tinggi dibandingkan dengan indeks pasar (misalnya IHSG). Sedangkan BNGA memiliki nilai beta yang negatif, yaitu -2.631 yang berarti bahwa return aset tersebut berkebalikan dengan return pasar. Secara umum return pasar akan selalu positif, apabila beta suatu saham negatif, artinya aset tersebut akan memberikan return yang lebih kecil dari tingkat keuntungan bebas risiko (aset tersebut memberikan return yang kecil).

Perhitungan varian dari kesalahan residu menunjukkan besarnya risiko tidak sistematik yang unik terjadi di dalam masing-masing saham, yang dihitung dengan rumus (5). BBNI memiliki nilai varian tertinggi yaitu 2.046, yang berarti bahwa disamping mempunyai ekspected return yang tinggi juga memiliki risiko yang tinggi pula (high risk high return), sedangkan risiko terendah ditawarkan oleh saham UNTR, dimana saham ini juga memiliki nilai ekspected return yang terendah.

Rasio ERB merupakan ukuran penilaian kinerja portofolio yang menunjukkan hubungan antara dua faktor penentu investasi yaitu return dan risiko. Portofolio yang optimal akan berisi dengan aktiva-aktiva yang mempunyai ERB yang tinggi. Rasio ERB dihitung dengan rumus (6). Dalam perhitungan tersebut diketahui bahwa saham TRUB memiliki nilai ERB terbesar yaitu 0.046, dimana nilai ERB yang besar akan memberikan keuntungan lebih diatas tingkat suku bunga bebas risiko. Jadi excess return di atas tingkat suku bunga bebas risiko berarti bila keuntungan bisa lebih dari 8\%. Sedangkan saham BNGA memiliki nilai ERB terendah yaitu sebesar -0.027. Dari perhitungan ini dapat dikatakan bahwa saham BNGA memiliki tingkat pengembalian yang kecil dibandingkan dengan aktiva bebas risiko, sehingga kemungkinan besar saham ini tidak akan masuk dalam portofolio optimal.

Langkah selanjutnya yakni menentukan saham-saham yang termasuk dalam portofolio optimal yaitu : 
1. Mengurutkan nilai ERB dari yang terbesar sampai dengan terkecil,

2. Menghitung Ai dan Bi dengan rumus (7.1) dan (7.2),

3. Menghitung Ci dengan rumus (7.3) dan menentukan Cut-Off Point yang merupakan batas nilai ERB berapa yang dikatakan tinggi, dengan demikian diketahui besarnya $\mathrm{C}^{*}$ adalah sebesar 0.0093, dimana angka ini diperoleh dari nilai ERB terakhir kali masih lebih besar dari Ci yaitu pada saham TINS (Timah Tbk).

Dengan demikian diperoleh portofolio optimal dan non-optimal. Sehingga dapat dihitung proporsi dana untuk masing-masing saham dengan rumus (8.1) dan (8.2). Dari urutan perhitungan diatas diperoleh hasil bahwa saham-saham yang membentuk portofolio optimal dan proporsi dana investasinya adalah sebagai berikut:

Tabel 2. Saham-Saham dalam Portofolio Optimal

\begin{tabular}{llcrccccc}
\hline No. & $\begin{array}{c}\text { Nama } \\
\text { Perusahaan }\end{array}$ & E(Ri) & $\beta_{i}$ & $\sigma_{e i}^{2}$ & ERBi & $\mathbf{C i}$ & $\mathbf{Z}$ & $\mathbf{W i}$ \\
& & & & & & & & \\
1 & TRUB & 0.160 & 1.753 & 0.059 & 0.046 & 0.0061 & 1.090 & $64.6 \%$ \\
2 & BUMI & 0.128 & 1.621 & 0.089 & 0.030 & 0.0078 & 0.377 & $22.3 \%$ \\
3 & BNBR & 0.115 & 1.277 & 0.355 & 0.028 & 0.0080 & 0.067 & $4 \%$ \\
4 & BBNI & 0.215 & 7.003 & 2.046 & 0.019 & 0.0086 & 0.033 & $2 \%$ \\
5 & ELTY & 0.115 & 2.023 & 1.183 & 0.018 & 0.0090 & 0.015 & $0.9 \%$ \\
6 & TINS & 0.098 & 1.302 & 0.046 & 0.013 & 0.0093 & 0.105 & $6.2 \%$
\end{tabular}

Saham TRUB mempunyai proporsi dana terbesar yakni sebesar 64.6\%, sedangkan saham ELTY hanya mendapat proporsi investasi sebesar $0.9 \%$. Dengan demikian dapat dihitung return serta risiko portofolio optimal dan nonoptimal dengan menggunakan rumus sebagai berikut :

$$
E\left(R_{P}\right)=\alpha_{P}+\beta_{P} . E\left(R_{M}\right) \text { dan } \sigma_{P}{ }^{2}=\beta_{P}{ }^{2} \cdot \sigma_{M}{ }^{2}+\left(\sum_{i=1}^{n} w_{i} \cdot \sigma_{e i}{ }^{2}\right)^{2}
$$

Sehingga diperoleh return ekspektasi portofolio optimal adalah sebesar $14.6 \%$ dan risikonya adalah sebesar $1.6 \%$. Dengan perhitungan yang sama diperoleh return ekspektasi portofolio nonoptimal adalah sebesar $7.8 \%$ dan risikonya sebesar $0.13 \%$.

Dengan dana yang dimiliki, investor dapat melakukan diversifikasi investasi sesuai keinginan investor. Dari keenam saham yang terbentuk ada kemungkinan investor dengan pertimbanganpertimbangan tertentu untuk dijadikan sebagai investasi, karena tiap-tiap investor mempunyai perilaku investasi yang tidak sama. Akan tetapi pemilihan portofolio dengan didukung oleh perhitungan yang matang seperti pada diatas, setidaknya akan mengurangi risiko yang terjadi dan dapat mengoptimalkan keuntungan investasi.

\section{E. KESIMPULAN DAN REKOMENDASI}

Penentuan portofolio optimal yang diperoleh dengan menggunakan Model Markowitz dan Model Indeks Tunggal terhadap 45 saham LQ45 di Bursa Effek, menemukan:

1. Pertama, dari 45 saham LQ45 diperoleh 44 saham yang memenuhi syarat $\mathrm{E}(\mathrm{Ri})>0$, dalam hal ini saham yang dikeluarkan adalah saham FREN (Mobile-8 Telecom Tbk) yang mempunyai $\mathrm{E}(\mathrm{Ri})$ terbesar. 
2. Dari 44 saham yang terpilih, ditentukan kembali saham yang mempunyai $E(R i)>R B R$, yaitu yang mempunyai tingkat pengembalian yang lebih besar daripada aktiva bebas risiko. Dari 44 saham tersebut diperoleh 11 saham yang kemudian diolah kembali untuk mencari risiko dan returnnya diantaranya yaitu melalui rasio ERB yang mengukur kelebihan return relatif terhadap satu unit resiko yang tidak dapat didiversifikasikan. Berdasarkan analisis resiko saham yang dinilai dengan varian kesalahan residu, serta tahap-tahap analisis model indeks tunggal, diperoleh 6 saham yang menjadi portofolio optimal yaitu saham TRUB (Truba Alam Manunggal Engineering Tbk), BUMI (Bumi Resources Tbk), TINS (Timah Tbk ), BNBR (Bakrie \& Brothers Tbk), BBNI (Bank Negara Indonesia Tbk), serta ELTY (Bakrieland Development Tbk).

3. Perbandingan return yang optimal dan yang non-optimal yakni Return ekspektasi portofolio optimal yang diperoleh adalah sebesar $14.6 \%$ dan risikonya sebesar $1.6 \%$. Sedangkan return ekspektasi pada portofolio non-optimal adalah sebesar $7.8 \%$ dan risikonya sebesar $0.13 \%$.

\section{DAFTAR PUSTAKA}

Baillie, Richard dan Patrick McMahon. 1990. The Foreign Exchange Market: Theory and Econometric Evidence. Cambridge University Press. Cambridge

Bursa Efek Jakarta. 2005. BEJ Laporan Tahunan 2005. http://www.bei.co.id/

Chen, N. F., R. Roll dan S. Ross. 1986. Economic Forces and the Stock Market. Journal of Business 59 (3).

Fabozzi, Frank J. 1999. Manajemen Investasi. Jakarta : Salemba Empat

Fardiansyah, Tedy. 2002. Kiat dan Strategi Menjadi Investor Piawai. Jakarta : PT Elex Media Komputindo

Fitriah, Laily. 2003. Analisis Portofolio Sebagai Salah Satu Alat Pengambilan Keputusan Investasi Saham di Pasar Modal (Studi Kasus Pada Perusahaan Semen Yang Go Publick). Skripsi. FIA UNIBRAW, Malang

Jogiyanto.2007. Teori Portofolio Dan Analisis Investasi. Yogyakarta : BPFE

Kuncoro, Mudrajad. 1993. Purchasing Power Parity: It's Nature, Deviation, and Implication for International Management. Kelola Gadjah Mada University Review. hal. 83, No. 7/III/1993

Sunariyah. 1997. Pengantar Pengetahuan Pasar Modal. Yogyakarta : UPP Akademi Manajemen Perusahaan YKPN

Supraptono. 2006. Prospek Industri Sekuritas 2007. Economic Review. No. 206. Desember 2006. http://www.bni.co.id/

Tandelilin, Eduardus. 2001. Analisis Investasi dan Manajemen Portofolio. Yogyakarta : BPFE

Tryfino. 2007. Prospek Investasi Di Bursa Efek Indonesia Tahun 2008. Economic Review. No. 210 Desember 2007.

Undang-Undang Republik Indonesia Nomor 8 Tahun 1995 Tentang Pasar Modal. 